\title{
BMJ Open Protected adults' voting rights: an interdisciplinary study of medical assessment and jurisprudence in France
}

\author{
Antoine Bosquet, ${ }^{1}$ Isabelle Mahé ${ }^{1,2}$
}

To cite: Bosquet A, Mahé I. Protected adults' voting rights: an interdisciplinary study of medical assessment and jurisprudence in

France. BMJ Open 2018;8:e020522. doi:10.1136/ bmjopen-2017-020522

- Prepublication history and additional material for this paper are available online. To view these files, please visit the journal online (http://dx.doi org/10.1136/bmjopen-2017020522).

Received 10 November 2017 Revised 11 May 2018 Accepted 8 June 2018

Check for updates

(C) Author(s) (or their employer(s)) 2018. Re-use permitted under CC BY-NC. No commercial re-use. See rights and permissions. Published by BMJ.

${ }^{1}$ Médecine Interne, Assistance Publique - Hôpitaux de Paris (AP-HP), Hôpital Louis Mourier, Colombes, France

${ }^{2}$ Assistance Publique - Hôpitaux de Paris (AP-HP), Recherche

Clinique Ville-Hôpital,

Méthodologies et Société (REMES) EA 7334, Université Paris Diderot, Colombes, France

Correspondence to

Dr Antoine Bosquet; antoine.bosquet@aphp.fr

\begin{abstract}
Objectives The study's objective was to describe the decision-making about voting rights of protected adults, which includes the medical assessment and the magistrate's decision to maintain voting rights or not. Design This work explores using an interdisciplinary approach: first, magistrate's decision-making with a systematic review of jurisprudence and second medical assessment with semistructured questionnaires sent to physicians assessing adults under guardianship.
\end{abstract}

Setting France.

Participants For jurisprudence's analysis, all guardianship decisions found on the Legifrance.gouv.fr website and that specified the protected person's voting rights were analysed. For the survey about medical civic assessment, an 18-item questionnaire was sent to all physicians drawing up medical certificates prior to placement under guardianship in one urban (Paris and the three surrounding departments) and one rural area of France (the 10 most rural French administrative departments).

Main outcome measures The analysis of jurisprudence explores the situation concerning protected adults' voting rights and the reasons for magistrates' decision. The survey about medical civic assessment explores the means of medical assessment (persons consulted, information collected), the content of the medical certificate, the physicians' opinions regarding their role. Results The analysis of the jurisprudence demonstrates that $30 \%(51 / 171)$ of protected adults kept the right to vote. The survey shows that medical assessment varied according to the physician's gender, specialty and geographical location. Voting capacity was the main criterion common to both physicians and magistrates in the decision whether to maintain voting rights. $27 \%$ (34/124) of physicians would like the official texts to be more precise, and one-third (41/133) wished to have tools to facilitate assessment of civic capacity.

Conclusions Official guides need to be drawn up to detail the criteria for and means of medical assessment of the civil capacity of protected adults, with a view to ensuring transparency and homogeneity in the exercise of justice.

\section{INTRODUCTION}

In democratic countries, the law allows voting rights to all citizens, regardless of any physical, psychological or cognitive disability. ${ }^{1}$ The principle of non-discrimination against the disabled is laid down in article 29 of the United

\section{Strengths and limitations of this study}

This study uses an interdisciplinary approach to assess both the medical and the legal decision-making about voting rights of protected adults in France.

- To the best of our knowledge, this study is the first to describe the medical civic assessment of the protected adults.

- In our study of the case law, only decisions which have been subject to a court challenge are found.

- The study of civic medical evaluation of protected adults was carried out on a declarative basis but to access a sample of medical certificates would be challenging.

Nations Convention on the Rights of Persons with Disabilities, ratified by a large number of countries, including France. ${ }^{2}$ Nevertheless, disability, ${ }^{3}$ and especially hospitalisation or living in an institution, ${ }^{4-10}$ is associated with lower involvement in electoral processes. There are moreover cases in which the law curtails civil rights in certain countries that are signatory to the convention, ${ }^{11}$ and being placed under guardianship is one such case. ${ }^{12}$ Three groups of countries can be distinguished according to protected persons' voting rights:

- Those that systematically curtail voting rights $^{13}$ : Germany, Bulgaria, Denmark, Greece, Ireland, Lithuania, Luxembourg and Poland.

- Those that institute an assessment procedure to determine voting rights ${ }^{12-15}$ : France, Spain, Estonia, Belgium, Hungary, Slovenia, Czech Republic, Australia and certain States in the USA; few of these explicitly define the voting capacity required in order to have the right to vote. $^{14-16}$

- And those that do not curtail protected persons' voting rights ${ }^{10-12}{ }^{17}$ : Austria, Croatia, Finland, Israel, Italia, Latvia, Norway, Netherlands, Portugal, Romania, the UK, Slovakia, Sweden, certain states in the USA and certain provinces in Canada. 
In France, persons can be placed under guardianship with ('curatelle' or 'curatorship') or without ('tutelle' or 'tutorship') systematic voting right. The present article refers to French persons placed under guardianship without systematic voting right only ('tutelle' or 'tutorship'). To improve reading, the terms of guardianship or protected persons are systematically used instead of the term tutorship, unless otherwise stated. In 2007, article L5 of the French electoral code ${ }^{18}$ stipulates that the magistrate supervising guardianship shall decide whether or not to maintain a protected adult's voting rights by referring to a detailed medical certificate drawn up by a physician registered with the public prosecutor's office (Procureur de la République). ${ }^{15}$ The certificate is to describe any impairment in the faculties of the person placed or to be placed under guardianship and any resulting need for assistance or representation in carrying out the acts of civic life, and the implications of such impairment on the exercise of the right to vote for adults under tutorship. ${ }^{20}$ The magistrate may refer for this to the person's community physician. ${ }^{21}$ The assessment is not standardised, ${ }^{22} 23$ and concerns a large number of citizens, especially in France, where some 350000 persons are protected (under tutorship). ${ }^{23}{ }^{24}$ In French law and in the available jurisprudence, ${ }^{24-26}$ neither voting capacity nor its assessment criteria are anywhere defined. In early $2017,{ }^{24}$ the National Consultative Commission on Human Rights $(\mathrm{CNCDH})$ highlighted the lack of data available on the application of article L5, and, controversially, ${ }^{26}$ argued that it should be rescinded and that all protected adults should enjoy the right to vote, in line with the UN Convention. $^{2}$

A recent national survey of French magistrates (juges d'instance) confirmed both the importance and the limitations of this detailed medical certificate ${ }^{27}$ : half of them reported that the certificate advised withdrawing voting rights without giving any reason and that, in such as case, the magistrate seldom if ever made a contrary decision. Sixty per cent reported that they seldom if ever maintain voting rights of persons under guardianship, which goes against the spirit of the 2007 reform. ${ }^{28} 29$ Given the lack of data on medical assessment of voting capacity, the aim of the present study was to analyse how physicians carry out the mission confide to them in law, ${ }^{20}$ with the support of a prior systematic analysis of the jurisprudence.

\section{MATERIAL AND METHODS Study objectives}

The main objective was to study physicians' means of assessing the impact of the protected person's impairment on his or her exercise of the right to vote, and to analyse the content of the detailed medical certificate. Secondary objectives were to compare assessment criteria between physicians and magistrates, and to collect physicians' opinions of their role with regard to protected persons' voting rights.

\section{Design of the study}

Step 1: An analysis of the jurisprudence on protected adults' voting rights was made in December 2016 using the Legifrance.gouv.fr website ${ }^{30}$ by selecting rulings according to the key terms 'tutelle' (tutorship) and 'droit de vote' (voting rights). Analysis concerned guardianship decisions that specified the protected person's voting rights. In every ruling, we have looked for the following criteria: reason for appealing, initial and final status of voting rights, magistrate's and physician's reasons given for voting status (online supplementary file 1).

Step 2: We built an 18-items questionnaire (online supplementary file 2) from questionnaires used in 2 of our previous studies $(8,9)$ and from an analysis of the literature $(1,7,14,15)$. It was sent by post to all registered physicians practising in urban (Paris and the three surrounding Departments: Hauts-de-Seine, Seine-SaintDenis and Val de Marne) and the 10 most rural administrative departments of France, ${ }^{31}$ (online supplementary file 3) in January 2017, and again in March in case of non-response. The response deadline was 24 April 2017. Registered physicians' addresses were obtained from the local Magistrates Courts (Tribunaux d'Instance). The questionnaire collected data on the number of protected persons assessed in 2016, the physician's seniority, characteristics of the protected adults, voting rights related elements collected during assessment and those figuring in the medical certificate, and the physician's opinions regarding his/her role, the protected adults in question (wish to vote, capacity to vote), and any difficulties encountered.

\section{Statistical analysis}

Mean values with SD were calculated on Microsoft Excel software. R software was used to compare characteristics between respondent and non-respondent physicians, and variations in assessments and in medical certificates or in different rulings ( $\chi^{2}$ and Fisher's exact tests).

\section{Consent statement}

Every participating physician gave a written consent to take part in this study.

\section{Patient and public involvement}

The development of the research question emerges from previous studies showing the attachment of inpatients and residents in the exercise of their voting rights. ${ }^{89}$ Protected adults and registered physicians were not involved in the design and the conduct of the study. The design of the study was presented to the CNCDH. ${ }^{24}$

\section{RESULTS}

\section{Analysis of jurisprudence on protected adults' voting rights}

Two hundred and two rulings were initially selected; 12 were excluded as not relating to guardianship and 18 as relating to guardianship but not in the form of tutorship (tutelle) with specification of voting rights. In one case, two 
Table 1 Guardianship rulings on appeal $(n=171)$

\begin{tabular}{|c|c|c|c|c|c|c|c|c|c|}
\hline \multicolumn{5}{|c|}{ Contested rulings } & \multicolumn{5}{|c|}{ Rulings on appeal } \\
\hline \multirow{3}{*}{$\begin{array}{l}\text { Court } \\
\text { District } \\
(n=159)\end{array}$} & \multicolumn{2}{|c|}{ Type of guardianship } & \multicolumn{2}{|c|}{$\begin{array}{l}\text { Voting rights } \\
\text { status }\end{array}$} & \multicolumn{2}{|c|}{$\begin{array}{l}\text { Final voting } \\
\text { rights status }\end{array}$} & \multirow{3}{*}{\begin{tabular}{|l}
$\begin{array}{l}\text { Ruling } \\
\text { explained }\end{array}$ \\
2 \\
1
\end{tabular}} & \multirow{3}{*}{$\begin{array}{l}\begin{array}{l}\text { Ruling not } \\
\text { explained }\end{array} \\
30 \\
0\end{array}$} & \multirow{3}{*}{$\begin{array}{l}\text { Court } \\
\begin{array}{l}\text { Appeals } \\
(n=159)\end{array}\end{array}$} \\
\hline & Tutorship & 152 & VR+ & 33 & VR+ & 32 & & & \\
\hline & & & & & VR- & 1 & & & \\
\hline & & & VR- & 119 & VR+ & 9 & $5^{\star}$ with $5^{\star}$ & 4 & \\
\hline & & & & & VR- & 110 & 10 with $1^{*}$ & 100 & \\
\hline & Curatorship & 7 & VR+ & 7 & VR+ & 4 & 1 & 3 & \\
\hline & & & & & VR- & 3 & 3 & 0 & \\
\hline \multirow{4}{*}{$\begin{array}{l}\text { Appeals } \\
(n=12)\end{array}$} & Tutorship & 12 & VR+ & 5 & VR+ & 5 & 4 & 1 & \multirow{4}{*}{$\begin{array}{l}\text { Supreme } \\
(n=12)\end{array}$} \\
\hline & & & & & VR- & 0 & 0 & 0 & \\
\hline & & & VR- & 7 & VR+ & 1 & 1 & 0 & \\
\hline & & & & & VR- & 6 & 3 with $1^{*}$ & 3 & \\
\hline \multicolumn{3}{|c|}{ Total rulings } & & & & & 30 with $7^{\star}$ & 141 & 171 \\
\hline
\end{tabular}

Appeals, Cour d'Appel; District, Tribunal d'Instance; Supreme, Cour de Cassation.

${ }^{*}$ Ruling in which voting rights was a grievance.

$\mathrm{VR}$, voting rights.

rulings concerned the same guardianship decision (same person and same date), and one was excluded. Finally, 171 rulings, made between 2011 and 2016, were analysed (table 1). Reasons for appealing an initial ruling were mostly single: choice of tutor (50\%), tutorship regimen $(27 \%)$ or other $(9 \%)$; in some cases, there were two reasons: tutorship regimen and choice of tutor $(10 \%)$, or tutorship regimen and voting rights (4\%). Twenty-three per cent of protected adults kept their voting rights after the initial ruling, and $30 \%$ on appeal (table 1). Fourteen rulings involved change in voting rights: 10 granting and 4 withdrawing voting rights; this mainly occurred when the issue of voting rights was contested $(71 \%$ vs $5.5 \%$, $\mathrm{p}=5.5 \times 10^{-5}$, Fisher's exact test).

In about $18 \%$ of rulings, the reasons for granting or withdrawing voting rights were explained, most often when the issue of voting rights was contested $(100 \%$ vs $\left.14 \%, \mathrm{p}=2 \times 10^{-6}\right)$ or when voting rights were changed $(71 \%$ vs $\left.13 \%, \mathrm{p}=4.1 \times 10^{-6}\right)$ : in $100 \%$ of cases of withdrawal and $60 \%$ of cases of granting voting rights. Twelve per cent of rulings in which the issue of voting rights was not contested and voting rights were not changed were also explained. Reasons given $(n=40)$ (table 2) were most often voting capacity $(n=19)$, wish to vote $(n=5)$, medical certificate indications in favour of or against voting rights $(n=5)$, interest in public affairs $(n=3)$ or insufficient justification for voting rights status in initial ruling $(n=3)$. Protected adults' voting capacity was usually $(17 / 19)$ assessed by the physician and this assessment was adopted by the magistrate; in the other two cases, the magistrate determined voting capacity without reference to the physician's opinion. No details were given of how the physician or magistrate assessed voting capacity, beyond statements such as 'lacks the lucidity to cast an informed vote $^{, 32}$ or 'his/her condition does not rule out a certain lucidity in terms of voting, ${ }^{33}$
In rulings that specified both the physician's and the magistrate's opinion on the protected person's voting rights, there was agreement in $93 \%$ of contested rulings $(14 / 15)$ and in $100 \%$ of rulings on appeal $(18 / 18)$.

Seven rulings were appealed because the person refused to lose his or her voting rights, sometimes associated with refusal of tutorship as such. Voting rights were restored

Table 2 Reasons given by magistrates for ruling on protected adult's voting rights (when given) $(n=171)$

\begin{tabular}{|c|c|c|c|c|c|c|c|c|}
\hline \multirow{2}{*}{$\begin{array}{l}\text { Reasons } \\
\text { Voting } \\
\text { capacity }\end{array}$} & \multirow{2}{*}{$\begin{array}{l}\begin{array}{l}\text { Rulings } \\
\text { with single } \\
\text { reason } \\
(n=24)\end{array} \\
17 \text { with } 3^{*}\end{array}$} & \multicolumn{6}{|c|}{$\begin{array}{l}\text { Rulings with several } \\
\text { reasons } \\
(n=6)\end{array}$} & \multirow{2}{*}{$\begin{array}{l}\text { Total } \\
\text { reasons } \\
19 \dagger\end{array}$} \\
\hline & & 0 & 0 & 1 & 0 & 0 & 1 & \\
\hline Wish to vote & 0 & 1 & 1 & 1 & 1 & 0 & 1 & 5 \\
\hline $\begin{array}{l}\text { Advice in } \\
\text { medical } \\
\text { certificate }\end{array}$ & 3 & 1 & 0 & 1 & 0 & 0 & 0 & 5 \\
\hline $\begin{array}{l}\text { Interest in } \\
\text { public affairs }\end{array}$ & 1 & 0 & 1 & 1 & 0 & 0 & 0 & 3 \\
\hline $\begin{array}{l}\text { Insufficient } \\
\text { motivation }\end{array}$ & 2 & 0 & 0 & 0 & 0 & 1 & 0 & 3 \\
\hline $\begin{array}{l}\text { Relief of } \\
\text { moral } \\
\text { suffering }\end{array}$ & 0 & 1 & 0 & 0 & 0 & 0 & 0 & 1 \\
\hline Other & 1 & 1 & 0 & 0 & 1 & 1 & 0 & 4 \\
\hline $\begin{array}{l}\text { Total } \\
\text { reasons }\end{array}$ & 24 with $3^{*}$ & $4^{*}$ & $2^{*}$ & 4 & $2^{*}$ & $2^{*}$ & 2 & 40 \\
\hline
\end{tabular}

${ }^{*}$ Ruling in which voting rights was a grievance $(n=7)$.

†In 2 of these 19 rulings, voting capacity was specified by the magistrate without referenced to the opinion of the physician; in the other 17 , voting capacity was indicated in the certificate and taken up as such by the magistrate. 
in five of these cases $(71 \%)$, the reason given being that voting capacity was conserved $(1 / 5)$, the person wished to vote $(3 / 5)$, with associated interest in public affairs in one case, or 'to relieve moral suffering' in another (table 2). In this last-mentioned case, voting rights were maintained 'despite the fact that (the protected adult) shows major impairment of physical and mental function'. ${ }^{34}$ Lack of voting capacity was the reason given for not restoring voting rights in the other two cases.

\section{Survey of protected persons' medical civic assessment Characteristics of the included registered physicians}

About $40 \%$ of registered physicians (124/309) responded to the questionnaire (online supplementary file 4): psychiatrists $(72 / 124,58 \%)$, geriatricians (29/124, $23 \%)$, community physicians $(16 / 124,13 \%)$, neurologists $(2 / 124,2 \%)$ or other specialists $(5 / 124,4 \%)$. They had been registered for assessment of protected adults for a mean 14 years (SD, 11). In 2016, they drew up 7426 certificates for various measures of protection (mean, 61 per physician per year; SD, 56; 121 responses) and 3159 for placement under tutorship (mean, 28 per physician per year; SD, 28, 114 responses). The population of responders was identical to the overall population of physicians initially contacted, in terms of specialty (psychiatrist or other; $\mathrm{p}=0.243, \chi^{2}$ ) and of location (Paris area or rural; $\mathrm{p}=0.579, \chi^{2}$ ).

\section{Assessment of adults for guardianship}

Online supplementary file 5 presents the characteristics of the adults for whom protection was considered. At assessment, 92\% of physicians looked for information concerning voting rights. Ninety-five per cent of these asked the person concerned, and $68 \%$ asked someone else (table 3). The information most often sought (table 4) concerned voting capacity $(98 \%)$, knowledge of political affairs $(90 \%)$ and the wish to vote $(87 \%)$. To assess voting capacity, physicians used the following criteria: severity of disorder $(98 / 110,89 \%)$, diagnosed pathology impairing cognitive functions $(83 / 110,75 \%)$, mini-mental state examination score, ${ }^{35}(83 / 110,75 \%)$, knowledge of current political affairs $(83 / 110,75 \%)$ or, less frequently, understanding of the electoral system $(41 / 110,37 \%)$ or a voting capacity assessment test $(14 / 110,13 \%)$.

After assessment, 53\% of physicians (60/113) considered that some persons under assessment still wished to vote (on average, $15 \%$ of persons; $\mathrm{SD}, 22 ; \mathrm{n}=45$ ), $26 \%$ $(29 / 113)$ considered the wish to be in all cases absent and $21 \%(24 / 113)$ had no opinion. Likewise, $42 \%$ $(46 / 110)$ reported that the person was in some cases an active voter (on average, $25 \%$ of persons; SD, 25; $\mathrm{n}=35$ ), $33 \%(36 / 110)$ that none were and 25\% (28/110) gave no information. Fifty-eight per cent $(62 / 107)$ considered voting capacity to be conserved in some cases (on average, in $26 \%$ of persons; SD, $24 ; \mathrm{n}=46$ ), $20 \%$ considered all their subjects to be incapable of voting and $22 \%$ (24/62) had no opinion.

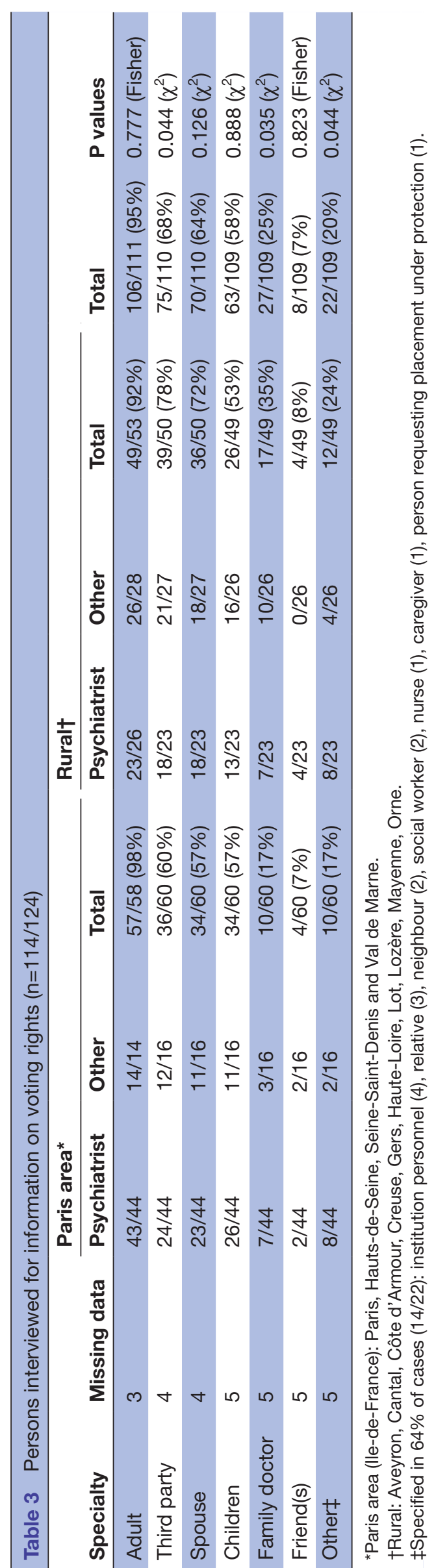


Table 4 Information on voting rights collected by registered physicians for medical assessment $(n=114)$

\begin{tabular}{|c|c|c|c|c|}
\hline Region & Paris area* & Rural† & Total & P values \\
\hline Voting capacity $\ddagger$ & $61 / 64$ (95.3\%) & $50 / 51(98 \%)$ & $111 / 113(98 \%)$ & 0.6282 (Fisher) \\
\hline $\begin{array}{l}\text { Knowledge of political } \\
\text { affairs }\end{array}$ & $57 / 64(90.5 \%)$ & $46 / 51(90.2 \%)$ & $103 / 114$ (90\%) & 1 (Fisher) \\
\hline Wish to vote & $52 / 63(82.6 \%)$ & 47/51 (92.2\%) & $99 / 114(87 \%)$ & 0.1681 (Fisher) \\
\hline Previous voting & $39 / 63$ (61.9\%) & 45/51 (88.2\%) & $84 / 114(74 \%)$ & $0.0015\left(\chi^{2}\right)$ \\
\hline On electoral roll & 19/63 (30.2\%) & $21 / 51$ (41.2\%) & $40 / 114(35 \%)$ & $0.2203\left(\chi^{2}\right)$ \\
\hline $\begin{array}{l}\text { With or without proxy } \\
\text { vote }\end{array}$ & 13/63 (20.6\%) & $18 / 51(35.3 \%)$ & $31 / 114(27 \%)$ & $0.0803\left(\chi^{2}\right)$ \\
\hline Other & 8/63 (12.7\%) & 13/51 (25.5\%) & $21 / 114(18 \%)$ & $0.0798\left(\chi^{2}\right)$ \\
\hline
\end{tabular}

${ }^{*}$ Paris area (lle-de-France): Paris, Hauts-de-Seine, Seine-Saint-Denis and Val de Marne.

†Rural: Aveyron, Cantal, Côte d'Armour, Creuse, Gers, Haute-Loire, Lot, Lozère, Mayenne, Orne.

¥No missing data except for voting capacity $(n=1)$.

Drawing up the detailed medical certificate

Ninety per cent of physicians included information on voting rights in the certificate (table 5 ), that is, voting capacity (86\%), impact of impairment on voting (83\%), recommendation to maintain or withdraw voting rights $(71 \%)$, wish to vote $(57 \%)$.

Variability of assessment and content of medical certificate according to physician's specialty and geographical area of practice

Psychiatrists more frequently interviewed the person as part of their assessment $\left(98.5 \%\right.$ vs $\left.88.4 \%, p=0.03, \chi^{2}\right)$. Physicians in rural practice more often questioned a third party, notably the family doctor (table 3 ). Information sought was usually independent of specialty and geography (table 4), although physicians in rural practice more often inquired about the risk of vote hijacking and less often about voting in previous elections (table 4). Female physicians more often inquired about wish to vote or on electoral roll (online supplementary file 6). The content of medical certificate is different according specialty or gender of physicians: psychiatrists more often mentioned the person's wish to vote and gave an opinion on maintaining voting rights (table 5) and male physicians more often mentioned voting capacity (online supplementary file 7).

Physicians' opinions on their role with respect to the voting rights of protected persons: legitimate capacity to fulfil this role, difficulties encountered and changes desired

About $80 \%$ of physicians $(95 / 120)$ considered their role relating to protected adults' voting rights to be legitimate, $9 \%(11 / 120)$ thought otherwise and 12\% $(14 / 120)$ expressed no opinion, independently of geography $\left(\mathrm{p}=0.54, \chi^{2}\right)$ and specialty (psychiatry or other, $\left.\mathrm{p}=0.96, \chi^{2}\right)$.

To make their task easier, $27 \%$ (34/124) would like the official texts to be more precise about the relevant criteria $(n=9)$ or the assessment of the risk of the person's vote being hijacked $(n=2)$; the others considered no changes necessary $(57 / 124,46 \%)$ or had no opinion $(33 / 124,27 \%)$. One-third $(41 / 133)$ wished to have tools available to help them; this mainly concerned rural physicians $\left(49 \%\right.$ vs $\left.29 \%, \mathrm{p}=0.034, \chi^{2}\right) ; 54 \%$ of

Table 5 Contents of detailed medical certificate $(n=124)$

\begin{tabular}{|c|c|c|c|c|c|}
\hline Specialty & $\begin{array}{l}\text { Missing } \\
\text { data }\end{array}$ & Psychiatrist & Other & Total & P values \\
\hline Information on voting rights & 2 & $63 / 72(87.5 \%)$ & $47 / 50(94.0 \%)$ & $110 / 122(90.2 \%)$ & 0.356 (Fisher) \\
\hline $\begin{array}{l}\text { Impact of cognitive } \\
\text { impairment on voting capacity }\end{array}$ & 9 & $49 / 59(83.1 \%)$ & $35 / 42(83.3 \%)$ & $84 / 101(83.2 \%)$ & $0.970\left(\chi^{2}\right)$ \\
\hline Voting rights maintained & 10 & $48 / 59(81.4 \%)$ & $24 / 42(57.1 \%)$ & $72 / 101(71.3 \%)$ & $0.008\left(\chi^{2}\right)$ \\
\hline Help in voting & 9 & $13 / 59(22.0 \%)$ & $6 / 42(14.3 \%)$ & 19/101 (18.8\%) & $0.326\left(\chi^{2}\right)$ \\
\hline Risk of vote being hijacked & 9 & $12 / 59(20.3 \%)$ & $7 / 42(16.7 \%)$ & $19 / 101(18.8 \%)$ & $0.642\left(\chi^{2}\right)$ \\
\hline $\begin{array}{l}\text { Help to prevent vote being } \\
\text { hijacked }\end{array}$ & 10 & $9 / 58(15.5 \%)$ & $5 / 42(11.9 \%)$ & $14 / 100(14.0 \%)$ & $0.607\left(\chi^{2}\right)$ \\
\hline
\end{tabular}


the others $(66 / 123)$ did not feel this need and $13 \%$ $(16 / 123)$ had no opinion.

Only $26 \%$ of physicians (31/121) reported encountering difficulties in the assessment of the impact of impairment on voting behaviour. Such difficulties were rarely expressed by the person being assessed or his/her family and friends $(2 / 30,7 \%)$, but more often by the physician (29/30, 97\%): difficulty in answering the question $(22 / 30,73 \%)$, difficulty of not granting voting rights although the person wished to remain able to vote $(3 / 31$, $10 \%)$, fear that the person's vote might get hijacked $(3 / 30,10 \%)$ or fear that the person might feel stigmatised by the loss of voting rights $(1 / 30,3 \%)$.

Physicians' opinions regarding protected persons' voting rights, independently of current legislation

When asked whether in their opinion protected adults should 'always, never or sometimes retain the right to vote', $10 \%(12 / 121)$ of physicians gave no opinion, $6 \%$ (7/121) answered 'always', 8\% (10/121) 'never' and 76\% (92/121) 'sometimes'. Reasons given, on an open question, with 67 responses, were: according to the degree of cognitive impairment $(37 / 67)$, conserved voting capacity $(14 / 67)$, type of pathology $(7 / 67)$, interest in voting $(6 / 67)$, knowledge of political affairs $(6 / 67)$, wish to vote $(5 / 67)$, habitual involvement in politics $(3 / 67)$, clinical condition according to disease exacerbation $(3 / 67)$ and risk of the person's vote being hijacked $(2 / 67)$.

\section{DISCUSSION}

\section{Statement of principal findings}

This study of the decision-making process for maintaining or withdrawing protected persons' voting rights, with a systematic analysis of the jurisprudence and of the assessment made by registered physicians, is to our knowledge the first in the field. Results found common criteria used by physicians and magistrates: voting capacity, wish to vote and interest in political affairs. The other points of interest were that the medical assessment and certificate differed according to the physician's gender, specialty and geographical location, and that when, exceptionally, the protected adult challenges the loss of voting rights, he or she usually wins their case.

\section{Strengths and limitations of the study}

In the jurisprudence analysis, the selected rulings $(n=171$ over a 6-year period) represented less than $0.1 \%$ of all protection rulings (of which there are some 180000 per year in France $)^{36}$; they may, however, have been the most interesting rulings, having been either appealed up to the Supreme Court of Appeal or else considered as instructive by a lower appeals court magistrate. ${ }^{37}$

The physicians included in the present study are responsible for drawing up some 7430 certificates per year, or about $4 \%$ of the yearly total of 180000 adult protection certificates in France. ${ }^{36}$ The present $40 \%$ response rate was comparable to those reported for other questionnaire studies. ${ }^{78}$ Responder characteristics were identical to those for the overall population of physicians initially contacted, and the results can thus be taken to be representative.

This work is not a comparative study of the medical and judicial criteria of decision concerning protected adults' voting rights. Indeed, there were no cases in where these criteria were compared directly.

\section{Meaning of the study: possible explanations and implications} for physicians and policy-makers

To our knowledge, there are no French data for the proportion of protected adults who keep their voting rights; some reports claim that a majority do so, ${ }^{26}$ other reports find the contrary, ${ }^{27}$ such as the present jurisprudence study, in which only a quarter of adults under guardianship retained the right to vote.

Voting capacity was the key point in medical assessment, and also the main reason given by magistrates for maintaining voting rights, in which they usually agreed with the physician's opinion. This is in line with the cardinal principle underlying guardianship: that, in the light of the medical certificate, the magistrate finds that the impairment of the faculties of the adult for whom guardianship is envisaged entails an inability to ensure alone his or her civil responsibilities, so that assistance and representation are required. ${ }^{21}$ This approach in terms of capacity thus implicitly applies to the exercise of voting rights, which raises many questions. First, is it possible to define the capacity to vote and who has the legitimacy to do that, second is it possible to assess the capacity to vote and if yes, who has the legitimacy to do that and with which tool. The prerequisite for a legitimate assessment of voting capacity would be to have a definition laid down by the legislative and judicial authorities, enabling assessment criteria to be determined. 'The definition of the criteria for capacity [notably, for voting] is [indeed] an exercise in policy, not science. ${ }^{14}$ In other words, physicians cannot legitimately make up their own definitions of voting capacity. The Competency Assessment Tool for Voting (CAT-V) was therefore designed by Appelbaum et $a l^{38}$ (online supplementary file 8) based on a definition of voting capacity put forward by the federal court of Maine: being able to understand the nature and effects of voting. ${ }^{39}$ Other definitions exist in Europe: in Slovenia, understanding the meaning, purpose and effects of voting or in the Czech Republic, understanding the meaning, purpose and consequences of an election. ${ }^{121316}$ The lack of a definition and of recognised assessment criteria for voting capacity and the lack of awareness of the CAT-V test on the part of French registered physicians (as revealed in personal contacts) probably explain why they found their opinions more on general and indirect criteria, such as severity of impairment, dementia or knowledge of political affairs, rather than on a functional assessment, whether formalised such as the CAT-V or not, in determining voting capacity. Using non-specific general 
criteria to assess voting capacity is, however, a possible source of error: persons with moderate Alzheimer's disease might, for example, wrongly be thought to have lost their voting capacity, or the converse, CAT-V scores being very variable in this situation. ${ }^{38}$ Moreover, the majority opinion among the registered physicians, that most protected adults are unable to vote, goes against the spirit of the 2007 reform of the French electoral code, which is to allow as many protected persons to vote as possible, implying a low threshold for voting capacity. ${ }^{28}$ The difficulty of assessing voting capacity can be seen in the physicians' opinions regarding their role: the difficulty of fulfilling the role was the main difficulty encountered; a quarter said that the official texts need to be more precise, especially as regards criteria and one-third wished for decision aids. And finally, lack of clarity regarding voting capacity may be enough to lead to a change in the protected person's voting rights in case of appeal. Conversely, specific assessment of voting capacity could also cause problems: some general, such as the impossibility of making an assessment if the person concerned, aware of the stakes, refuses to cooperate, and others more specifically related to the use of a tool such as the CAT-V, which fails to take account of certain specificities such as voting in a referendum or by procuration, which is possible in France and in the $\mathrm{UK}^{40}$ and does not easily determine capacity except for extreme scores, ${ }^{38}$ all of which are little-known features of the CAT-V. Moreover, during the CAT-V interview, the person being assessed could consider that the communication of the choice of his favourite candidate and the reasons of his choice undermines the idea of a secret ballot. When a democracy institutes assessment of voting capacity for certain citizens, the rules should be set by legitimate judicial and parliamentary authorities, and be known to all.

After voting capacity, the wish to vote is the assessment criterion most often used by physicians and magistrates. In rulings in which voting rights were a reason for appeal, the wish to vote was cited as often as voting capacity $(3 / 7)$ and was systematically put forward without the latter being mentioned. Allowing a protected person to vote because he or she so wishes is considered to be a way of relieving moral suffering despite severe cognitive impairment. ${ }^{34}$ The wish to vote was not specified in more than $40 \%$ of medical certificates, although physicians usually asked about it (tables 4 and 5). The reason for this may be that physicians consider that most protected persons no longer wish to vote, that a wish to vote makes no sense in someone considered incapable of voting, as it does not correlate with voting capacity. ${ }^{38}$ Depriving a protected adult of the right to vote because he or she no longer has the wish to do so is problematic, as the wish may vary according to what is at stake in such and such an election. Moreover, it goes against the principle of assessing capacity, which is at the heart of guardianship. However, as the wish to vote was a frequent factor for magistrates' decisions regarding voting rights, physicians should include it in their medical certificates to facilitate the task of the magistrate, who may not be able to determine the person's wishes in court, through lack of time $\mathrm{e}^{24}$ or because the person is absent.

The means of assessment and the certificate differed according to the physician's gender, specialty and geographical location. Non-psychiatrists less often mentioned in their certificates the person's wish to vote or stated their opinion as to voting rights, although, after voting capacity, these are the factors most used by magistrates in coming to a decision (table 2). Physicians also differed in how often they questioned the person to be protected and his or her network when collecting information relevant to voting rights. Interviewing the person should be mandatory; interviewing the network may provide crucial information. This can be seen in one case history: an adult placed under guardianship without the right to vote recovered his voting rights on appeal, partly thanks to the testimony of his social worker, who testified that he still had the capacity to vote, as he followed the news and kept up to date concerning parties and candidates, and knew exactly who he would vote for and was therefore badly affected by losing this right. ${ }^{24}$ The heterogeneity of medical certificates has previously been reported in a general way, ${ }^{22}{ }^{23}$ but not with specific reference to voting rights. There are many reasons for this: the lack of official criteria and assessment guidelines, the lack of mandatory training and of precise competency criteria for registered physicians, although this has been proposed. ${ }^{41}$ No medical assessment is going to be perfectly reproducible, but some agreement on official criteria and on the contents of the certificate could only help in harmonising assessment, and would facilitate the work of the registered physicians and of magistrates, who often regret a lack of detail in the certificate, especially regarding voting rights. ${ }^{27}$

Voting rights appear seldom to be a subject of grievance for the protected person or the family, considering the small proportion of appeals following withdrawal of voting rights and the rarity of such grievance being mentioned by the physician. One reason may be that most of the persons under assessment no longer wish to vote, according to most registered physicians, although some of them may have underestimated the person's wish to vote.

\section{Conclusion and future research}

Prior assessment of protected adults' possibility of enjoying voting rights, as it exists in France, is preferable to systematic withdrawal of rights but is also in contradiction with the Convention on the Rights of Persons with Disabilities. ${ }^{2}$ The present study highlighted the fact that, despite the lack of explicit official criteria, the main factor used by registered physicians and by magistrates to decide on protected adults' voting rights is the capacity to vote. Physicians inappropriately do not use a functional assessment of capacity to vote but rather indirect methods. The other important findings are: that medical assessment varied according to physician characteristics; that the wish 
to vote was not always specified in medical certificates, whereas it is often the sole reason given by the magistrate for maintaining voting rights and that some registered physicians expressed a need for changes such as clearer official texts and assessment tools. It is therefore necessary to draw up and publish official guidelines in France, specifying the criteria and means of medical assessment of civic status for persons placed under guardianship, for the sake of transparency and respect for the principle of equality before the law. The role of the registered physician would be thereby facilitated, and the needs of magistrates would be more adequately met. Comparative study of implementation of legislation in countries where, as in France, voting rights are determined on a case-by-case basis, or others in which voting rights are systematically maintained, would be of great interest.

Acknowledgements We acknowledge the contributions of Aline Bosquet, jurist and Yves Bosquet, Doctor of Law, for their careful reading of the article. We also acknowledge all the doctors who took the time to answer the questionnaire.

Contributors Study design and interpretation of data: $A B$ and IM. Jurisprudence review, analysis of data and paper drafting: $A B$. Paper revision: IM. $A B$ is the guarantor of the study.

Funding The authors have not declared a specific grant for this research from any funding agency in the public, commercial or not-for-profit sectors.

Competing interests None declared.

Patient consent Not required.

Ethics approval Permission to collect and process data for this study was approved by the data protection committee (Commission Nationale de I'Informatique et des Libertés).

Provenance and peer review Not commissioned; externally peer reviewed.

Data sharing statement Additional data are available: online supplementary files 1-8.

Open access This is an open access article distributed in accordance with the Creative Commons Attribution Non Commercial (CC BY-NC 4.0) license, which permits others to distribute, remix, adapt, build upon this work non-commercially, and license their derivative works on different terms, provided the original work is properly cited, appropriate credit is given, any changes made indicated, and the use is non-commercial. See: http://creativecommons.org/licenses/by-nc/4.0/.

\section{REFERENCES}

1. Karlawish JH, Bonnie RJ, Appelbaum PS, et al. Addressing the ethical, legal, and social issues raised by voting by persons with dementia. JAMA 2004;292:1345-50.

2. United Nations. Convention on the Rights of Persons with Disabilities. Art 29 http://www.ohchr.org/EN/HRBodies/CRPD/Pages/ ConventionRightsPersonsWithDisabilities.aspx\#29

3. Schur L, Ameri M, Adya M. Disability, Voter Turnout, and Polling Place Accessibility. Soc Sci Q 2017;98:1374-90.

4. Redley M, Hughes JC, Holland A. Voting is a political right, not a matter of competence to make decision. BMJ 2010;341:466-7.

5. Smith $H$, Humphreys $M$. Changes in laws are necessary to allow patients detained under Mental Health Act to vote. BMJ 1997;315:431.

6. Aylett V, Cook G, Corrado OJ. Measures are needed to allow elderly inpatients to vote in general elections. BMJ 1998;316:552.

7. Karlawish JH, Bonnie RJ, Appelbaum PS, et al. Identifying the barriers and challenges to voting by residents in nursing homes and assisted living settings. J Aging Soc Policy 2008;20:65-79.

8. Bosquet A, El Massioui F, Mahé I. Conditions for exercising residents voting rights in long-term care residences: a prospective multicenter study. J Aging Soc Policy 2015;27-47-62.

9. Bosquet A, Medjkane A, Voitel-Warneke D, et al. The vote of acute medical inpatients: a prospective study. J Aging Health 2009;21:699-712.
10. Doron A, Kurs R, Stolovy T, et al. Voting rights for psychiatric patients: compromise of the integrity of elections, or empowerment and integration into the community? Isr J Psychiatry Relat Sci 2014;51:169-74.

11. Bhugra D, Pathare S, Gosavi C, et al. Mental illness and the right to vote: a review of legislation across the world. Int Rev Psychiatry 2016;28-395-9.

12. Gurbai $S$. The right to vote of adults placed under guardianship in the light of international law, European regional law and comparative public law. 2015. Thesis. https://jak.ppke.hu/uploads/articles/12332/ file/Gurbai_dolg_v(1).pdf

13. FRA European Union Agency for Fundamental Rights (2010). The right to political participation of persons with mental health problems and persons with intellectual disabilities. file:///D:/Users/3002577/ Downloads/1216-Report-vote-disability_EN.pdf (assessed 4 Jul 2018).

14. Hurme SB, Appelbaum PS. Defining and Assessing Capacity to Vote: The Effect of Mental Impairment on the Rights of Voters. McGeorge Law Review 2007;38:931-79.

15. Bosquet A, Medjkane A, Vinceneux P, et al. [Voting by cognitively impaired persons: legal and ethical issues]. Psychol Neuropsychiatr Vieil 2010;8:33-42.

16. Gurbai S. Le droit des personnes déficientes intellectuelles ou ayant des troubles d'origine psychosociale:In. Érès, ed. Gardien $E$, Des innovations sociales par et pour les personnes en situation de handicap. Toulouse. France: connaissances de la diversité, 2012:71-87.

17. Representation of the People Act. 2000 https://www.legislation.gov. uk/ukpga/2000/2/schedule/4 (assessed 4 Jul 2018).

18. Electoral Code. Art 5. French https://www.legifrance.gouv.fr/ affichCodeArticle.do;?idArticle=LEGIARTI000006353025\&cidTexte= LEGITEXT000006070239 (assessed 4 Jul 2018).

19. Noguéro D. Le certificat médical pour l'ouverture des mesures de protection des majeurs. Revue de recherche juridique 2011;3:1227-52

20. Code de procédure civile. Art 1219. French https://www.legifrance. gouv.fr/affichCodeArticle.do?cidTexte=LEGITEXT000006070716\& idArticle=LEGIARTI000020031149 (assessed 4 Jul 2018).

21. Code civil. Art 431 (consultation médecin traitant) consulté le 10/09/2017 sur Legifrance. https://www.legifrance.gouv.fr/ affichCodeArticle.do?cidTexte=LEGITEXT000006070721\&idArticle= LEGIARTI000006427590\&dateTexte=\&categorieLien=cid. French (assessed 5 Nov 2017).

22. Eyraud B. Protéger et rendre capable. Toulouse. France: Érès, 2014. French.

23. Cour des comptes. La protection juridique des majeurs. Une réforme ambitieuse, une mise en œuvre défaillante. 2016. French https:// www.ccomptes.fr/sites/default/files/EzPublish/20161004-rapportprotection-juridique-majeurs.pdf (assessed 4 Jul 2018).

24. Commission Nationale Consultative des Droits de l'Homme. Avis sur le droit de vote des personnes handicapées: Citoyenneté et handicap « le droit de vote est un droit, pas un privilège », 2017. French. http://www.cncdh.fr/fr/publications/avis-sur-le-droit-de-vote-despersonnes-handicapees (assessed 4 Jul 2018).

25. Blatman M. Rapport au défenseur des droits. L'effet direct des stipulations de la Convention internationale relative aux droits des personnes handicapées. 2016. French https://www. defenseurdesdroits.fr/sites/default/files/atoms/files/02._rapport_de_ michel_blatman.pdf (assessed 4 Jul 2018).

26. Noguéro D. Election, droit de vote, droits fondamentaux et majeurs protégés. JDSAM 2017;16:128-37 http://www.institutdroitsante.fr/ wp-content/uploads/2017/04/jdsam-n16.pdf

27. Fondation Médéric Alzheimer. Lettre de l'observatoire. 2016;45:1-9. French http://www.fondation-mederic-alzheimer.org/Informez-vous/ La-Lettre-de-I-Observatoire/Archives

28. Senat. Annexe au procès-verbal de la séance ordinaire du 15 juin 2006 (annex to the minutes of the sitting of 15 June 2006 à revoir). About N. 2006. French https://www.senat.fr/leg/ppl05-406.html (assessed 4 Jul 2018).

29. Senat. Sitting of 22 February 2007. Compte-rendu des débats. 2007. French http://www.senat.fr/seances/s200702/s20070222/ s20070222010.html\#int1831 (assessed 4 Jul 2018).

30. Légifrance. Site officiel de diffusion du droit. Rubrique jurisprudence judiciaire. https://www.legifrance.gouv.fr/initRechJuriJudi.do (assessed 4 Jul 2018).

31. Institut national de la statistique et des études économiques (INSEE). Structure de la population active de 25 à 54 ans selon la catégorie socioprofessionnelle, selon le niveau de diplôme, selon le sexe ou le secteur d'activité (1968 à 2013). French https://www.insee.fr/fr/ statistiques/1893185 (assessed 4 Jul 2018). 
32. CA Lyon. N²5/10/028461. 2011. French https://www.legifrance. gouv.fr/affichJuriJudi.do?oldAction=rechJuriJudi\&idTexte $=$ JURITEXT000023537452\&fastReqld $=2120137714$ \&fastPos $=171$ (assessed 5 Nov 2017).

33. CC Paris (ch civ 1). N ${ }^{\circ} 14-18578.2015$. French https://www. legifrance.gouv.fr/affichJuriJudi.do?oldAction=rechJuriJudi\&idTexte= JURITEXT000030792515\&fastReqld $=71298207 \&$ fastPos $=183$ (assessed 5 Nov 2017).

34. CA Rennes. Nº14/04123. 2015. French. https://www.legifrance. gouv.fr/affichJuriJudi.do?oldAction=rechJuriJudi\&idTexte $=$ JURITEXT000031517547\&fastReqld $=1198032576 \&$ fastPos $=36$ (assessed 5 Nov 2017).

35. Folstein MF, Folstein SE, McHugh PR. "Mini-mental state". A practical method for grading the cognitive state of patients for the clinician. J Psychiatr Res 1975;12:189-98.
36. Ministère de la Justice. République française. Références Statistiques Justice. 2014. French http://www.justice.gouv.fr/art_pix/ Stat_Annuaire_ministere-justice_interactif.pdf

37. Code de l'organisation judiciaire. (sélection des décisions sur legifrance) Art $R^{\star} 131-16-1$. French https://www.legifrance.gouv.fr/ affichCodeArticle.do?cidTexte=LEGITEXT000006071164\&idArticle= LEGIARTI000006519657 (assessed 4 Jul 2018).

38. Appelbaum PS, Bonnie RJ, Karlawish JH. The capacity to vote of persons with Alzheimer's disease. Am J Psychiatry 2005;162:2094-100.

39. v Doe. Rowe, 156 F. Supp.2d 35 (D. Me. 2001).

40. Inclusion Europe. 2011 http://inclusion-europe.eu/wp-content/ uploads/2015/04/Good_Practices_EN.pdf (assessed 4 Jul 2018),

41. Le livre Blanc sur la protection juridique des majeurs (CHAPE, FNAT, UNAF, UNAPEI). 2012. http://www.unaf.fr/IMG/pdf/livre_blanc_bd2. pdf French. (assessed 4 Jul 2018) 